\title{
Species composition and spatial variability of macroalgal assemblages on biogenic reefs in the northern Adriatic Sea
}

\begin{abstract}
We sampled macroalgal assemblages on 37 rocky outcrops in the northern Adriatic over the last 2 decades by SCUBA. Macroalgal assemblages were rich (173 taxa), but there was high variability in the number of species and coverage. The morphology of the outcrops, the distance from the coast and the depth were identified as the main factors accounting for this variability. Both the mean total algal coverage (14.8\%) and encrusting layer coverage $(8.0 \%)$ were low when compared to typical Mediterranean coralligenous habitats. Four main groups of algal assemblages were distinguished on the basis of their species composition and coverage. Groups 1 and 3 were located inshore off the Lido inlet and south of it, and had, respectively, low or intermediate total algal cover. Group 2 included outcrops situated offshore from the Venice lagoon along with all outcrops off the GradoMarano lagoon; these had the highest total algal cover. Finally, group 4 included assemblages comprising algae that were widespread on outcrops in the inshore habitats of the Venice lagoon, between Malamocco and Chioggia inlets. Offshore outcrops subject to low turbidity and eutrophication levels had several characteristic Mediterranean coralligenous taxa.
\end{abstract}

Keywords: coralligenous assemblages; macroalgae; Mediterranean; Northern Adriatic Sea; rocky outcrops.

\footnotetext{
*Corresponding author: Annalisa Falace, Dip. Scienze della Vita, Università Trieste Via L. Giorgieri, 34127 Trieste, Italia, e-mail: falace@univ.trieste.it

Daniele Curiel: SELC Soc. Coop. Via dell'Elettricità 3/D, 30175 Marghera, Venezia, Italia

Vinko Bandelj and Cosimo Solidoro: OGS, Ist. Naz. Oceanografia e Geofisica Sperimentale, B.go Grotta Gigante, Briščiki 42/c, 34010 Sgonico, Zgonik (TS), Italia

Sara Kaleb: Dip. Scienze della Vita, Università Trieste Via L. Giorgieri, 34127 Trieste, Italia

Enric Ballesteros: Centre d'Estudis Avançats de Blanes, CSIC, Accés Cala Sant Francesc, 14, E-17300 Blanes, Girona, Espana
}

\section{Introduction}

Coralline algal bioconstructions constitute key habitats in the complex mosaic of Mediterranean biodiversity; among them, coralligenous assemblages are the most widespread and are considered an important hot spot of biodiversity (Ballesteros 2006). Coralligenous reefs can be defined as a biogenic substratum produced by accumulation of both calcareous encrusting algae growing in dim light conditions and fauna (mainly bryozoans, serpulids, corals and sponges) that contribute to developing and consolidating the framework formed by the calcareous algae (Hong 1980, Ballesteros 2006). The northern Adriatic Sea is scattered with hundreds of rocky outcrops, initially interpreted as beach rocks (Braga and Stefanon 1969, Stefanon 1970, Newton and Stefanon 1975), but current knowledge suggests that they are most likely related to seeping methane and cementation and lithification processes (Colantoni et al. 1998, Stefanon and Zuppi 2000, Conti et al. 2002, Gordini et al. 2004). The assemblages developing over these structures are similar to those reported for coralligenous outcrops outside the northern Adriatic (Casellato and Stefanon 2008), but they have some striking differences that make them unique (Falace, unpublished data).

Location, depth, topography and geological structure of the northern Adriatic rocky outcrops are well known (Braga and Stefanon 1969, Newton and Stefanon 1975), as are biodiversity and spatio-temporal variability of zoobenthic assemblages (Mizzan 1992, Gabriele et al. 1999, Casellato et al. 2005, 2007, Casellato and Stefanon 2008, Ponti and Mescalchin 2008, Molin et al. 2010, Ponti et al. 2011). However, phycological studies started recently, and only partial results have been published (Curiel et al. 2001, Curiel and Molin 2010, 2010a,b, Kaleb et al. 2011, Gordini et al. 2012).

The aims of this study were (1) to broaden knowledge of species composition and structure of macroalgal assemblages growing on rocky outcrops of the northern Adriatic, (2) to investigate their spatial variability and 
(3) to search for main environmental variables and geo-morphological features that could account for the observed variability.

\section{Materials and methods}

\section{Study area}

The rocky outcrops studied are located in the northern Adriatic Sea in an area extending from the Gulf of Venice to the Gulf of Trieste, in the proximity of the Venice and the GradoMarano lagoons $\left(45^{\circ} 13^{\prime}-45^{\circ} 39^{\prime} \mathrm{N} ; 12^{\circ} 20^{\prime}-13^{\circ} 28^{\prime} \mathrm{E}\right)$. The reefs have a rocky base (local calcareous sediments cemented by seeping methane, Stefanon and Zuppi 2000) that hosts the growth of calcareous bio-concretions. These reefs are surrounded by sedimentary bottoms (Trincardi et al. 1994) in which the sandy fraction prevails in offshore locations, with mud and clay dominant in the inshore localities. The distance from the coast is 0.5 to $21 \mathrm{~km}$ and depths range from 7 to $25 \mathrm{~m}$ (Figure 1, Table 1). Dominant sea currents are driven by cyclonic geostrophic circulation (Artegiani et al. 1997a,b, Solidoro et al. 2009). Strong seasonal halocline and thermocline are present, and the light is estimated to be $1 \%-2 \%$ of the mean surface irradiance (Franco 1984, Bernardi-Aubry et al. 2004) at all depth ranges.
The morphology of northern Adriatic rocky outcrops may be classified as "banks with more or less horizontal substrata” (sensu Pérès and Picard 1964, Laborel 1987), and their dimensions vary from $1-2 \mathrm{~m}^{2}$ to $1000 \mathrm{~m}^{2}$ (Casellato and Stefanon 2008). Their extent and morphology are very diverse, but may be categorized into three basic typologies: i) type 1: widespread rocks with low relief (0.5-1 m); ii) type 2: clustered rocks with low relief (0.5-1 m); iii) type 3: wide structures, with relief up to $3-4 \mathrm{~m}$ (Table 1).

\section{Sampling and laboratory analyses}

We collated and re-analyzed the data collected over approximately 15 years on 37 rocky outcrops (Figure 1, Table 1), and partial results have been published (Curiel et al. 2001, 2010a,b, Curiel and Molin 2010, Falace et al. 2010a,b, Gordini et al. 2012). Samples were collected in spring through early summer on the upper horizontal surfaces of the outcrops by scraping and collecting all macroalgae with a vacuum lift on three randomly selected quadrats of $2500 \mathrm{~cm}^{2}$. Species compositions and coverage (Boudouresque 1971) were determined in the laboratory. When possible, all the macroalgae were identified to specific or lower levels using the most recent taxonomic literature. For species with insignificant

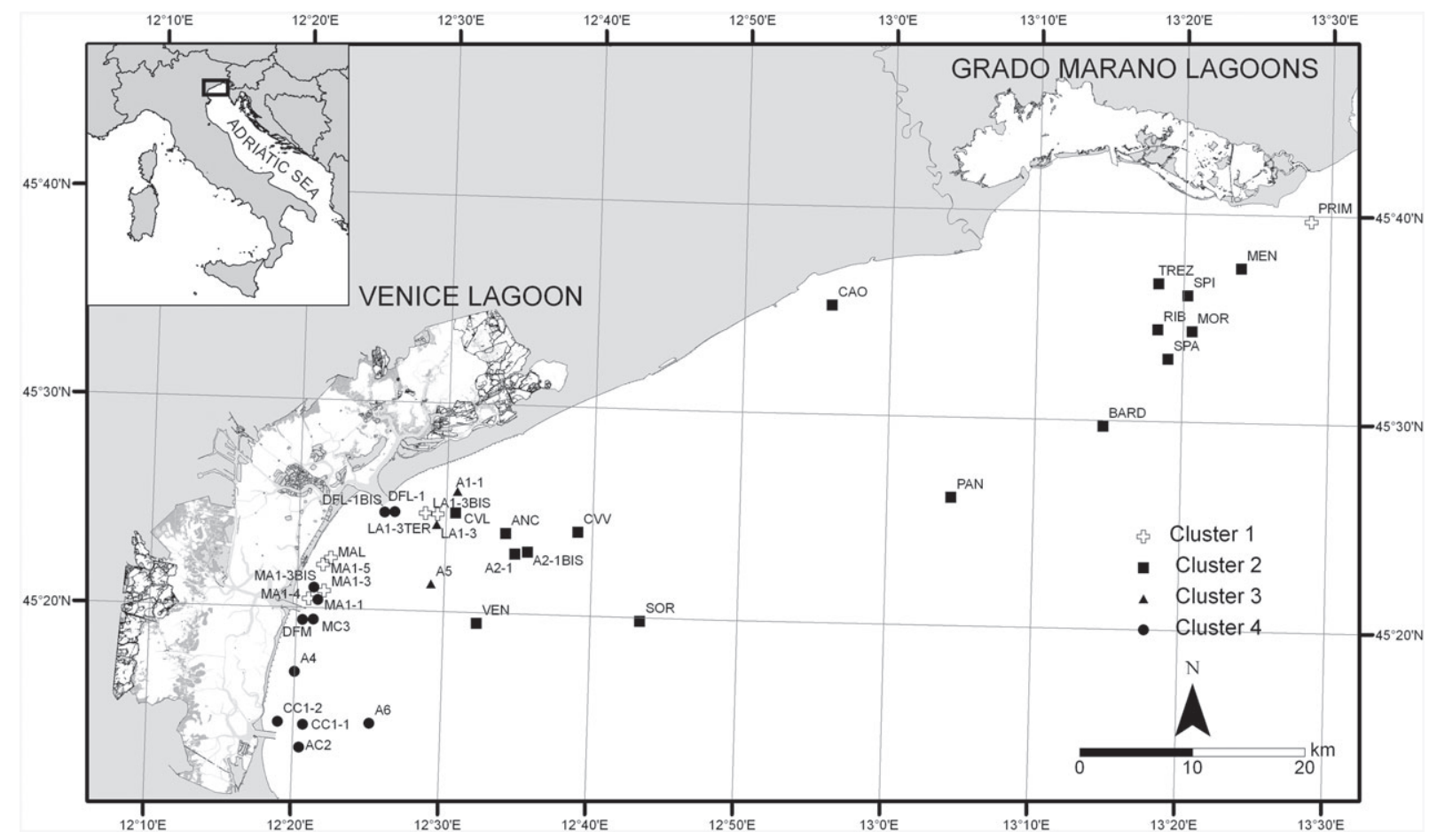

Figure 1 Geographical distribution of the rocky outcrops sampled. Different symbols correspond to clusters obtained in Figure 3. 


\begin{tabular}{|c|c|c|c|c|c|c|c|}
\hline Site & $\begin{array}{r}\text { Morphology } \\
\text { (type) }\end{array}$ & Depth (m) & $\begin{array}{r}\text { Distance to } \\
\text { coast (km) }\end{array}$ & Site & $\begin{array}{r}\text { Morphology } \\
\text { (type) }\end{array}$ & Depth (m) & $\begin{array}{r}\text { Distance to } \\
\text { coast (km) }\end{array}$ \\
\hline A1-1 & 3 & 14 & 3 & LA1-3TER & 3 & 14 & 3.9 \\
\hline A2-1 & 2 & 19 & 9.7 & MA1-1 & 1 & 10 & 1 \\
\hline$A 2-1 B I S$ & 2 & 19 & 9.8 & MA1-3 & 2 & 10 & 1.9 \\
\hline A4 & 2 & 10 & 1.9 & MA1-3BIS & 2 & 10 & 1.9 \\
\hline A5 & 1 & 17 & 8.5 & MA1-4 & 1 & 8 & 1 \\
\hline A6 & 1 & 20 & 8.3 & MA1-5 & 1 & 7 & 1.4 \\
\hline $\mathrm{AC2}$ & 1 & 15 & 2.2 & MAL & 1 & 9 & 1.7 \\
\hline ANC & 3 & 18 & 7.5 & MC3 & 1 & 12 & 1 \\
\hline BARD & 3 & 19 & 19 & MEN & 1 & 14 & 4.8 \\
\hline CAO & 2 & 10 & 2.8 & MOR & 3 & 19 & 10.9 \\
\hline CC1-1 & 1 & 16 & 1.2 & PAN & 3 & 25 & 21.2 \\
\hline $\mathrm{CC} 1-2$ & 1 & 9 & 2.5 & PRIM & 3 & 10 & 2.5 \\
\hline CVL & 3 & 20 & 9.9 & RIB & 2 & 21 & 11.5 \\
\hline CVV & 3 & 15 & 4.3 & SPI & 3 & 15 & 7.4 \\
\hline DFL-1 & 1 & 10 & 0.5 & SOR & 3 & 22 & 19.3 \\
\hline DFL-1BIS & 1 & 10 & 0.5 & SPA & 3 & 19 & 13.8 \\
\hline DFM & 1 & 9 & 0.7 & TREZ & 2 & 13 & 7.6 \\
\hline LA1-3 & 3 & 14 & 3.9 & VEN & 2 & 20 & 13.3 \\
\hline LA1-3BIS & 3 & 14 & 3.9 & & & & \\
\hline
\end{tabular}

Table 1 Rocky outcrops morphology and main environmental variables.

See Figure 1 for locations of sites. Morphology categories: type 1, widespread rocks with low relief (0.5-1 m); type 2, clustered rocks with low relief (0.5-1 m); type 3, wide structures with relief up to 3-4 m.

abundances, a nominal coverage value of $0.01 \%$ was assigned.

The number of species, total algal coverage, Shannon index, coverages of encrusting, turf and erect algae and coverages of Chlorophyta, Rhodophyta and Ochrophyta (Phaeophyceae) were estimated for every sample, and relationships of these parameters and environmental variables, such as type of substratum, depth and distance from the coast, were evaluated by non-parametric Spearman rank order correlations.

Ordination and cluster analysis were performed to explore the variability of macroalgal assemblages between the different outcrops and identify discrete groups of samples with similar species composition and abundances. We used a two-step procedure based on selforganizing maps (SOMs), a neural network, unsupervised, iterative numerical algorithm (Kohonen 2001) for nonlinear projection and ordination of multidimensional data onto a lower dimensional (usually 2D) lattice made by map units, to which model vectors are associated. Based on their multi-dimensional similarity, original data are projected on the map units so that similar data are grouped in the same or neighboring map units. Model vectors of map units may be further analyzed by classical hierarchical or partitive clustering methods (Solidoro et al. 2007a, Bandelj et al.2008) to obtain a smaller number of easily described clusters. For the clustering of map units, we used the
Ward's minimum variance method (Legendre and Legendre 1998). SOM has already been successfully applied in other ecological studies (Lek and Guégan 1999, Giraudel and Lek 2001, Park et al. 2004, Bandelj et al. 2008). The original algal cover data were first transformed by $\chi^{2}$ metric transformation (Legendre and Gallagher 2001) to prevent the "double zero" problem (Legendre and Legendre 1998) and to give higher weight to rare species. The transformed data were then analyzed with the SOM Toolbox for Matlab routines. The SIMPER test (Clarke 1993) was used to determine species responsible for multivariate patterns.

\section{Results}

A total of 173 macroalgal taxa were collected and identified, of which 124 were Rhodophyta, 25 Ochrophyta and 24 Chlorophyta (Appendix I). The species richness per sample was $25.6 \pm 17.0( \pm S D)$, with a minimum of six taxa (LA1 3 BIS) and a maximum of 97 taxa (SPI) per sample (Table 2). The mean macroalgal coverage was $14.8 \% \pm 29.2 \%$, with the lowest values found on the outcrops close to the Venice lagoon and the highest on the outcrop SPI offshore the Gulf of Trieste (Table 2).

Rhodophyta were the most frequent and abundant taxa (Figure 2A, Table 2), although a high variability was 


\begin{tabular}{|c|c|c|c|c|c|c|c|c|c|}
\hline & $\begin{array}{r}\text { Number of } \\
\text { species }\end{array}$ & Coverage (\%) & $\mathrm{H}^{\prime}$ & $\begin{array}{r}\text { Encrusting } \\
\text { (cover \%) }\end{array}$ & $\begin{array}{r}\text { Erect } \\
\text { (cover \%) }\end{array}$ & $\begin{array}{r}\text { Turf } \\
\text { (cover \%) }\end{array}$ & $\begin{array}{r}\text { Chlorophyta } \\
\text { (cover \%) }\end{array}$ & $\begin{array}{r}\text { Ochrophyta } \\
\text { (cover \%) }\end{array}$ & $\begin{array}{r}\text { Rhodophyta } \\
\text { (cover \%) }\end{array}$ \\
\hline A1-1 & 21 & 1.9 & 1.7 & 0.5 & 1.2 & 0.2 & 0.0 & 0.0 & 1.8 \\
\hline$A 2-1$ & 33 & 4.4 & 1.3 & 3.9 & 0.2 & 0.3 & 0.0 & 0.2 & 4.2 \\
\hline A2-1BIS & 32 & 5.6 & 1.3 & 4.7 & 0.1 & 0.8 & 0.0 & 0.2 & 5.4 \\
\hline A4 & 16 & 2.0 & 0.9 & 0.0 & 1.9 & 0.1 & 0.5 & 0.0 & 1.5 \\
\hline A5 & 8 & 0.0 & 1.5 & 0.0 & 0.0 & 0.0 & 0.0 & 0.0 & 0.0 \\
\hline A6 & 11 & 4.4 & 0.2 & 0.1 & 4.3 & 0.1 & 4.3 & 0.0 & 0.1 \\
\hline $\mathrm{AC} 2$ & 23 & 6.0 & 0.4 & 0.0 & 5.9 & 0.1 & 5.5 & 0.3 & 0.2 \\
\hline ANC & 38 & 2.1 & 1.6 & 1.9 & 0.1 & 0.1 & 0.0 & 0.0 & 2.0 \\
\hline BARD & 61 & 100.8 & 2.4 & 82.9 & 14.4 & 3.4 & 3.2 & 15.9 & 81.7 \\
\hline CAO & 39 & 4.1 & 1.8 & 1.3 & 2.7 & 0.1 & 0.0 & 0.3 & 3.9 \\
\hline CC1-1 & 12 & 4.5 & 0.7 & 0.0 & 4.3 & 0.2 & 3.8 & 0.3 & 0.5 \\
\hline CC1-2 & 20 & 9.5 & 1.4 & 0.0 & 5.0 & 4.5 & 4.2 & 0.2 & 5.1 \\
\hline CVL & 18 & 1.1 & 1.7 & 0.9 & 0.2 & 0.1 & 0.0 & 0.0 & 1.1 \\
\hline CVV & 18 & 0.6 & 1.6 & 0.6 & 0.0 & 0.0 & 0.0 & 0.0 & 0.6 \\
\hline DFL-1 & 42 & 3.0 & 1.8 & 0.0 & 2.3 & 0.7 & 2.1 & 0.1 & 0.9 \\
\hline DFL-1BIS & 27 & 2.9 & 1.3 & 0.0 & 2.3 & 0.6 & 2.2 & 0.1 & 0.7 \\
\hline DFM & 37 & 24.5 & 1.8 & 0.0 & 19.3 & 5.2 & 13.3 & 4.4 & 6.8 \\
\hline LA1-3 & 21 & 0.4 & 2.0 & 0.2 & 0.2 & 0.0 & 0.0 & 0.0 & 0.4 \\
\hline LA1-3BIS & 6 & 0.1 & 1.1 & 0.0 & 0.1 & 0.0 & 0.0 & 0.0 & 0.1 \\
\hline LA1-3TER & 8 & 0.2 & 1.4 & 0.0 & 0.1 & 0.0 & 0.0 & 0.0 & 0.2 \\
\hline MA1-1 & 35 & 10.2 & 1.6 & 0.2 & 8.6 & 1.5 & 3.0 & 0.1 & 7.2 \\
\hline MA1-3 & 31 & 12.2 & 1.4 & 0.2 & 11.2 & 0.9 & 2.4 & 0.0 & 9.8 \\
\hline MA1-3BIS & 27 & 4.6 & 2.2 & 0.0 & 2.1 & 2.4 & 0.7 & 0.0 & 3.8 \\
\hline MA1-4 & 22 & 4.0 & 1.5 & 0.1 & 2.4 & 1.5 & 0.2 & 0.0 & 3.8 \\
\hline MA1-5 & 36 & 9.2 & 1.7 & 0.2 & 6.5 & 2.5 & 0.3 & 0.0 & 8.9 \\
\hline MAL & 13 & 2.5 & 1.4 & 0.0 & 1.5 & 1.1 & 0.0 & 0.0 & 2.5 \\
\hline MC3 & 22 & 7.3 & 1.3 & 0.0 & 3.7 & 3.6 & 6.2 & 0.2 & 0.9 \\
\hline MEN & 7 & 11.1 & 0.6 & 10.6 & 0.0 & 0.5 & 0.0 & 0.0 & 11.1 \\
\hline MOR & 12 & 14.4 & 0.5 & 14.2 & 0.2 & 0.1 & 0.1 & 0.2 & 14.1 \\
\hline PAN & 17 & 34.6 & 1.9 & 30.6 & 2.7 & 1.3 & 0.2 & 0.9 & 33.5 \\
\hline PRIM & 21 & 3.7 & 1.4 & 0.2 & 0.6 & 2.9 & 0.0 & 0.0 & 3.7 \\
\hline RIB & 16 & 53.0 & 1.4 & 49.0 & 0.5 & 3.6 & 0.0 & 1.7 & 51.4 \\
\hline SPI & 97 & 147.9 & 3.0 & 70.7 & 48.4 & 28.9 & 17.8 & 46.3 & 83.8 \\
\hline SOR & 35 & 3.3 & 1.6 & 3.2 & 0.0 & 0.1 & 0.0 & 0.1 & 3.1 \\
\hline SPA & 22 & 21.3 & 1.9 & 13.6 & 0.3 & 7.4 & 1.8 & 0.2 & 19.3 \\
\hline TREZ & 14 & 16.1 & 1.8 & 5.9 & 0.8 & 9.5 & 0.3 & 0.0 & 15.8 \\
\hline VEN & 13 & 1.4 & 1.6 & 1.3 & 0.0 & 0.0 & 0.0 & 0.4 & 0.9 \\
\hline Min & 6 & 0.04 & 0.2 & 0.00 & 0.00 & 0.01 & 0.00 & 0.00 & 0.04 \\
\hline Max & 97 & 147.9 & 3.0 & 82.9 & 48.4 & 28.9 & 17.8 & 46.3 & 83.8 \\
\hline Mean \pm SD & $25.6 \pm 17.0$ & $14.8 \pm 29.2$ & $1.5 \pm 0.5$ & $8.2 \pm 19.3$ & $4.2 \pm 8.6$ & $2.3 \pm 5.0$ & $2.0 \pm 3.8$ & $2.0 \pm 8.0$ & $10.8 \pm 20.2$ \\
\hline
\end{tabular}

Table 2 Number of species per sample, total percentage coverage, Shannon diversity, coverage of encrusting, erect and turf algae and coverage of green, brown and red algae at each of the sampling stations.

Data are averages of three replicates. See Table 1 and Figure 1 for sampling sites.

detected, with the Rhodophyta ranging from $50 \%$ to $100 \%$ of total taxa from each outcrop, the Chlorophyta from $0 \%$ to $33 \%$ and the Ochrophyta from $0 \%$ to $19 \%$. Rhodophyta had a mean coverage of $10.8 \% \pm 20.2 \%$, the Ochrophyta of $2 \% \pm 8.0 \%$ and the Chlorophyta of $2 \% \pm 3.8 \%$ (Table 2 ). The coverage by phylum also varied greatly among the outcrops, ranging from $0 \%$ to $84 \%$ of the total coverage for the Rhodophyta, from $0 \%$ to $18 \%$ for the Chlorophyta and from $0 \%$ to $46 \%$ for the Ochrophyta (Table 2). The more abundant taxa were coralline algae and Peyssonneliaceae (Peyssonnelia dubyi, P. harveyana, P. polymorpha, P. rosamarina, P. squamaria, Lithothamnion philippii and Lithophyllum pustulatum) and foliose Rhodophyta (Rhodymenia ardissonei and Cryptonemia lomation). Amongst the Ochrophyta and Chlorophya Zanardinia typus and Ulva laetevirens were, respectively, the most abundant species.

The number of turf algae (13.4 \pm 9.0 taxa) was higher than the encrusting (6.4 \pm 5.6 taxa) and the erect ones 

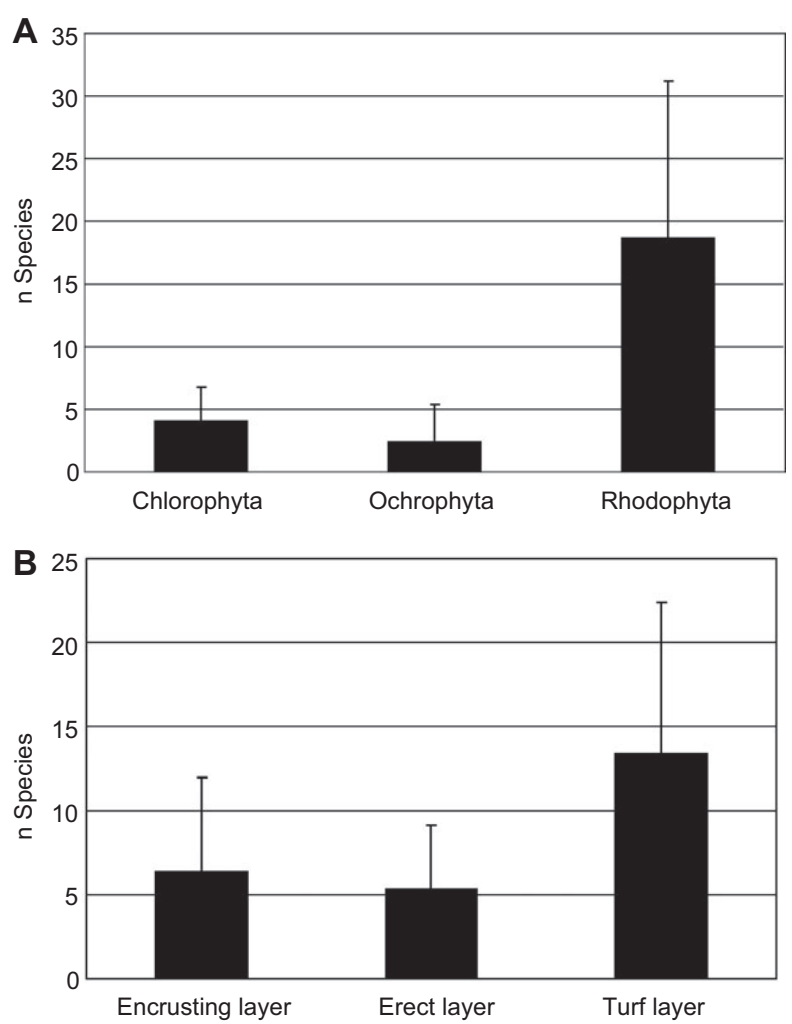

Figure 2 (A, B) Total number of taxa in each algal phylum (A) and each vegetation stratum (means+SD, $n=3$ ). $n$, number.

(5.4 \pm 3.8 taxa) (Figure 2B). Different results were obtained considering the mean coverage values: $8.2 \% \pm 19.3 \%$ for encrusting algae, which prevailed over the erect $(4.2 \% \pm 8.6 \%)$ and turf algae $(2.3 \% \pm 5.0 \%)$ (Table 2$)$.

Type 1 outcrops had high coverage of Chlorophyta and erect algae, low values of the Shannon index and low coverage of encrusting algae (Table 3). In contrast, outcrops of type 3 had high values of Shannon index and high coverage of encrusting algae, but low values of Chlorophyta coverage. Moreover, type 1 outcrops were mostly situated in shallow waters near the coast, whereas type 3 outcrops were located in the deeper offshore waters. Depth was negatively correlated with erect algal coverage, but positively correlated with encrusting algal coverage. Distance from coast, which is well correlated with depth $(R=0.86$, $\mathrm{p}<0.05$ ), had the same correlation pattern, plus a significant negative correlation with Chlorophyta coverage.

The SOM non-linear ordination analysis resulted in a map of $5 \times 6$ units (Figure 3). A partitioning into four clusters was identified as most appropriate for further considerations based on visual inspection of sample ordinations on the map and on the levels of diversity between clusters in the dendrogram (Figure 1), taking into account similarity percentage (SIMPER) analysis of species abundances (Table 4).

First, the outcrops were divided between those on the right part of the SOM (clusters 2 and 4), where the majority of the sampling sites are projected, and those on the left part of the SOM, with fewer outcrops (clusters 1 and 3). The outcrops of clusters 1 and 3, mainly substratum type 1 and type 3, had a restricted number of significant taxa: the encrusting Peyssonnelia sp. in cluster 3 and Aglaothamnion tenuissimum, A. tripinnatum and Rhodophyllis divaricata in cluster 1 (Table 4). The species defining cluster 3 are common in northern Adriatic shallow rocky outcrops, both over natural and artificial substrata. Cluster 3 grouped only three rocky outcrops at intermediate distances (mean $4 \mathrm{~km}$ ) off the Lido inlet (Figure 1) at a mean depth of $14 \mathrm{~m}$; these are characterized by very low total algal cover (Figure 4). Cluster 1 comprised outcrops located near to shore (mean distance from coast $1.9 \mathrm{~km}$ ) off the Lido inlet and south of it, with the exception of PRIM off the Grado-Marano lagoon (Gulf of Trieste) (Figure 1). Outcrops in cluster 1 occurred in shallow waters (mean depth $10 \mathrm{~m}$ ) and had intermediate values of total algal cover (mean 15\%) (Figure 4).

The rocky outcrops included in cluster 2 were mainly of substratum types 2 and 3 and were largely characterized by the red algae Peyssonnelia dubyi, P. harveyana, P. rosa-marina, P. squamaria, Lithothamnion philippii, Lithophyllum pustulatum and the brown algae Cutleria chilosa, Halopteris filicina and Sphacelaria plumula

\begin{tabular}{|c|c|c|c|c|c|c|c|c|c|}
\hline & nsp & Cover & $H^{\prime}$ & Enc. & Erect & Turf & Chl & Och & Rho \\
\hline Type1 & -0.04 & 0.06 & $-0.34^{\star}$ & $-0.62^{\star}$ & $0.37^{*}$ & 0.17 & $0.41 *$ & -0.02 & -0.25 \\
\hline Type2 & 0.06 & 0.11 & 0.00 & 0.21 & -0.09 & 0.04 & -0.07 & 0.15 & 0.25 \\
\hline Type3 & -0.01 & -0.16 & $0.34^{*}$ & $0.43^{*}$ & -0.29 & -0.21 & $-0.34^{\star}$ & -0.12 & 0.03 \\
\hline Depth & -0.21 & 0.05 & -0.04 & $0.56^{*}$ & $-0.43^{*}$ & -0.31 & -0.26 & 0.31 & 0.03 \\
\hline Dist. coast & -0.20 & 0.12 & 0.15 & $0.78^{\star}$ & $-0.49^{\star}$ & -0.18 & $-0.39 *$ & 0.21 & 0.28 \\
\hline
\end{tabular}

Table 3 Non-parametric Spearman rank order correlations between site characteristics (see Table 1 for site details) and algal variables. Nsp, number of species; cover, total coverage; H', Shannon diversity index; Enc, encrusting algae; erect, erect algae; turf, turf algae; Ch, Chlorophyta; Och, Ochrophyta; Rho, Rhodophyta; dist. coast, distance to coast. Correlations marked with * are significant at $\mathrm{p}<0.05$. 

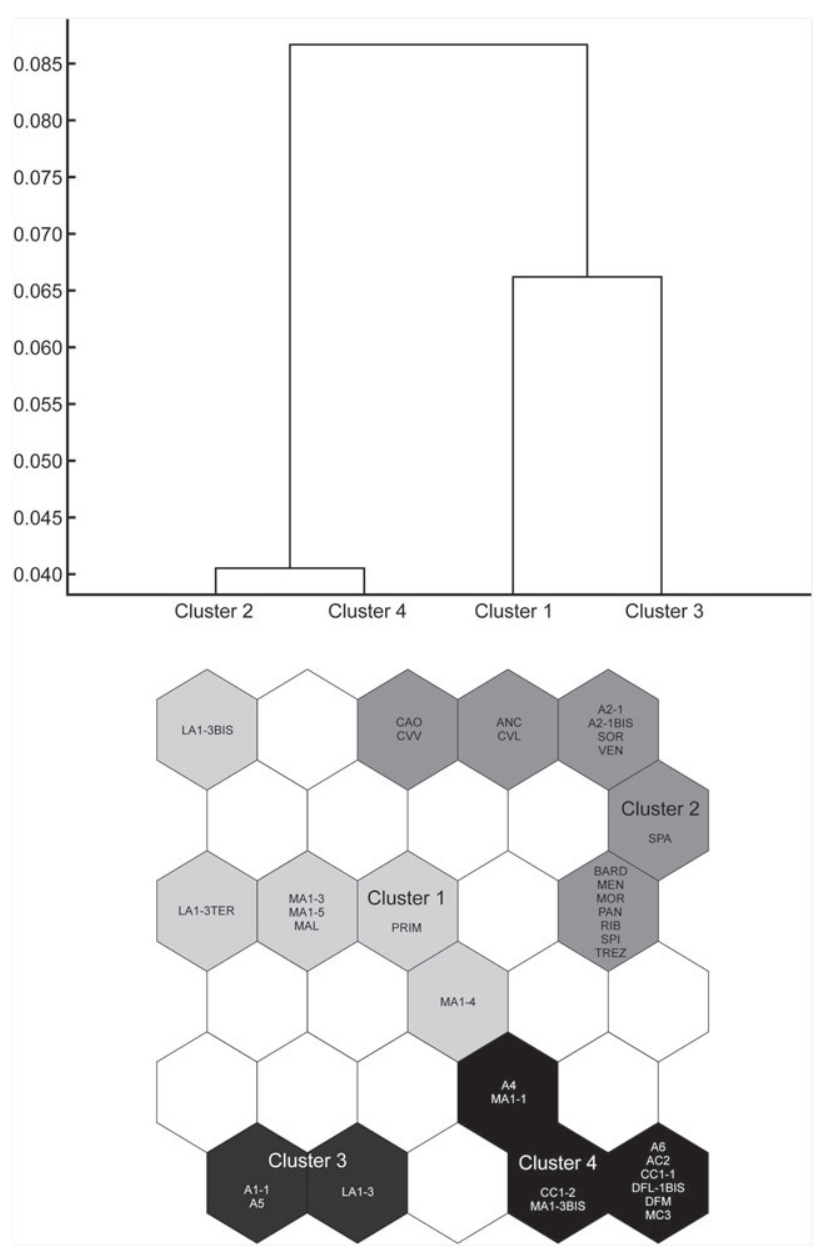

Figure 3 Dendrogram obtained using Ward's minimum variance method of frequency (upper graphic) and self-organizing maps (SOMs) (lower graphic). For the geographical location of the stations, see Figure 1.

(Table 4). Cluster 2 grouped the rocky outcrops situated offshore (mean distance $10 \mathrm{~km}$ ) from the Venice lagoon, along with all sampling sites off the Grado-Marano Lagoon found in deeper water (mean $19 \mathrm{~m}$ ) (Figure 1) and characterized by the highest total algal cover (mean 33\%), with some extreme values for stations BARD and SPI. In particular, these last two outcrops were characterized by a high number of taxa (61-97), total coverage (100\%$148 \%)$, encrusting algae ( $71 \%-83 \%$ coverage), erect algae (15\%-48\% coverage), Ochrophyta $(16 \%-4 \%$ coverage) and Rhodophyta ( $82 \%-84 \%$ coverage). Finally, cluster 4 comprised rocky outcrops characterized by algae that are widespread in the inshore habitats of the Venice lagoon, between the Malamocco and Chioggia inlets (Figure 1): the red algae Chondria capillaris, Dasya baillouviana, D. hutchinsiae, Gracilariopsis longissima, Polysiphonia morrowii, Radicilingua reptans and $R$. thysanorhizans, the brown alga Dictyota dichotoma v. intricata and the green algae Ulva laetevirens and Chaetomorpha linum (Table 4). Outcrops grouped in cluster 4 were mainly of substratum type 1 situated at depths of $10 \mathrm{~m}$ (Figure 1 ) at a mean distance of only $1.2 \mathrm{~km}$ from the shore. They had intermediate total coverages of algae (mean 19\%).

\section{Discussion}

The present number of macroalgal taxa reported for northern Adriatic rocky outcrops amounts to 190 (Solazzi and Tolomio 1981, Ponti et al. 2011, this study), with red algae being dominant, both in species number and abundance. Boudouresque (1973) reported 315 macroalgal species for deep-water macroalgal Mediterranean sciaphilic assemblages, whereas a total of 187 epiphytic macroalgal species were observed on the coralligenous assemblages off Tuscany's coasts and islands (northwestern Mediterranean Sea) (Piazzi et al. 2011). Thus, the algal assemblages growing in these Adriatic outcrops can be considered to have a high species richness. Moreover, they include a high percentage of the flora of the region as the total number of macrophytes reported for the Gulf of Trieste amounts to 220 taxa (Falace 2000). Nevertheless, the mean total algal coverage $(14.8 \% \pm 29.2 \%$, with an encrusting algal cover of $80 \% \pm 193 \%$ ) was low when compared to values reported in coralligenous assemblages (total cover $>120 \%$, with an encrusting algal cover $>90 \%$, Piazzi et al. 2004, Ballesteros 2006). These differences are difficult to explain, but they may be attributable to the high environmental variability in the physico-chemical and trophic parameters of the water column (Stefanon and Boldrin 1982, Soresi et al. 2004, Casellato et al. 2005, Solidoro et al. 2009, Ponti et al. 2011), the reduced extension of the outcrops, the surrounding muddy sediments (AA. VV. 2010, Ponti et al. 2011) and the reduced depth at which they develop. Moreover, the particulate organic matter enhances the colonization on the rocky outcrops of filter feeders, such as sponges, tunicates, bryozoans and some polychaetes (Mizzan 1992, Gabriele et al. 1999, Casellato et al. 2005, 2007, Ponti and Mescalchin 2008, AA. VV. 2010, Ponti et al. 2011), which can outcompete macroalgae and perhaps explain the low percentage of algal cover observed. Only some encrusting species or taxa that grow attached to the substratum, such as Peyssonnelia spp., Lithothamnion philippii, Lithophyllum pustulatum and Zanardinia typus, attained a large coverage.

The total cover of algal taxa had great variability in relation to the morphology of the outcrops, distance from the coast, depth and geographical location. On the 
Simper classification

\begin{tabular}{|c|c|c|c|c|c|c|c|}
\hline Cluster 1 & Contr. \% & Cluster 3 & Contr. \% & Cluster 2 & Contr. \% & Cluster 4 & Contr. \% \\
\hline $\begin{array}{l}\text { Cryptonemia } \\
\text { lomation }\end{array}$ & 21 & $\begin{array}{l}\text { Rhodymenia } \\
\text { ardissonei }\end{array}$ & 26 & $\begin{array}{l}\text { Rhodymenia } \\
\text { ardissonei }\end{array}$ & 15 & Ulva laetevirens & 40 \\
\hline $\begin{array}{l}\text { Rhodophyllis } \\
\text { divaricata }\end{array}$ & 18 & $\begin{array}{l}\text { Peyssonnelia } \\
\text { sp. } 1\end{array}$ & 26 & $\begin{array}{l}\text { Peyssonnelia } \\
\text { harveyana }\end{array}$ & 15 & $\begin{array}{l}\text { Radicilingua } \\
\text { thysanorhizans }\end{array}$ & 10 \\
\hline $\begin{array}{l}\text { Rhodymenia } \\
\text { ardissonei }\end{array}$ & 16 & $\begin{array}{l}\text { Cryptonemia } \\
\text { lomation }\end{array}$ & 13 & $\begin{array}{l}\text { Peyssonnelia } \\
\text { rosa-marina }\end{array}$ & 13 & $\begin{array}{l}\text { Gracilariopsis } \\
\text { longissima }\end{array}$ & 10 \\
\hline $\begin{array}{l}\text { Lithophyllum } \\
\text { pustulatum }\end{array}$ & 13 & $\begin{array}{l}\text { Aglaothamnion } \\
\text { sp. }\end{array}$ & 13 & $\begin{array}{l}\text { Lithophyllum } \\
\text { pustulatum }\end{array}$ & 12 & $\begin{array}{l}\text { Dictyota dichotoma v. } \\
\text { intricata }\end{array}$ & 9 \\
\hline $\begin{array}{l}\text { Rhodymenia } \\
\text { pseudopalmata }\end{array}$ & 6 & $\begin{array}{l}\text { Lithophyllum } \\
\text { pustulatum }\end{array}$ & 10 & $\begin{array}{l}\text { Lithothamnion } \\
\text { philippii }\end{array}$ & 7 & $\begin{array}{l}\text { Chondria } \\
\text { capillaris }\end{array}$ & 5 \\
\hline $\begin{array}{l}\text { Aglaothamnion } \\
\text { tenuissimum }\end{array}$ & 5 & $\begin{array}{l}\text { Radicilingua } \\
\text { thysanorhizans }\end{array}$ & 3 & $\begin{array}{l}\text { Gelidium } \\
\text { pusillum }\end{array}$ & 7 & $\begin{array}{l}\text { Radicilingua } \\
\text { reptans }\end{array}$ & 4 \\
\hline Aglaothamnion sp. & 4 & & & Cutleria chilosa & 7 & Chaetomorpha linum & 4 \\
\hline $\begin{array}{l}\text { Radicilingua } \\
\text { thysanorhizans }\end{array}$ & 4 & & & $\begin{array}{l}\text { Peyssonnelia } \\
\text { dubyi }\end{array}$ & 6 & $\begin{array}{l}\text { Rhodymenia } \\
\text { ardissonei }\end{array}$ & 4 \\
\hline $\begin{array}{l}\text { Aglaothamnion } \\
\text { tripinnatum }\end{array}$ & 3 & & & $\begin{array}{l}\text { Sphacelaria } \\
\text { plumula }\end{array}$ & 2 & $\begin{array}{l}\text { Dasya } \\
\text { hutchinsiae }\end{array}$ & 3 \\
\hline $\begin{array}{l}\text { Antithamnion } \\
\text { cruciatum }\end{array}$ & 2 & & & $\begin{array}{l}\text { Peyssonnelia } \\
\text { squamaria }\end{array}$ & 2 & $\begin{array}{l}\text { Nitophyllum } \\
\text { punctatum }\end{array}$ & 2 \\
\hline & & & & Cryptonemia lomation & 1 & Ceramium diaphanum & 2 \\
\hline & & & & Radicilingua thysanorhizans & 1 & & \\
\hline & & & & Peyssonnelia sp. & 1 & & \\
\hline
\end{tabular}

Table 4 SIMPER (similarity percentage analysis) output of macroalgal classification into four clusters of rocky outcrops obtained in SOM (self-organizing map) analysis.

Contr. \%, \% contribution to differentiation of clusters.

inshore outcrops situated near the fluvial inflows (Po, Brenta, Piave, Tagliamento) and the Venice and GradoMarano lagoons, the algal coverage was almost zero and the substratum was mainly covered by sediment; in contrast, rocky outcrops situated further offshore attained total algal coverages of $70 \%-80 \%$. At intermediate distances from the coast, the calcified taxa of the genus Peyssonnelia prevailed, while offshore rocky outcrops were dominated by species of the genus Lithophyllum and Lithothamnion. This shift in species abundances is in accordance with the findings of Hong (1980), who observed that with increasing degree of disturbance, the Corallinales are replaced by the Peyssonneliaceae, which have a much lower building capacity (Sartoretto 1996). On the rocky outcrops, even where the turf-forming and filamentous algae were numerically dominant, there was always low coverage, with the exception of Pseudochlorodesmis furcellata. In contrast, the encrusting algae, such as Lithophyllum incrustans, Lithothamnion minervae, L. philippii, Peyssonnelia harveyana, P. polymorpha, and $P$. rosa-marina, had reduced coverage on the inshore rocky outcrops, but they were abundant on the offshore ones characterized by low turbidity and sedimentation. Our results are in agreement with others authors (Morganti et al. 2001, Balata et al. 2004, 2005, 2007), who described a varying structure of coralligenous assemblages and a great spatial and temporal variability between areas characterized by different water turbidity and sediment deposition. Furthermore, as we sampled only on the horizontal surfaces, rocky outcrops are not very high (up to $4 \mathrm{~m}$ ) and are surrounded by muddy substrata, the effect of sediment deposition should be important. In fact, as observed by Balata et al. (2005, 2007), turf-forming species become abundant on high sediment deposition horizontal surfaces whereas the abundance of encrusting algae is strongly reduced as a consequence of the combined effects of low light levels, burial and scouring (Balata et al. 2007). In particular among the turf-forming species, $P$. furcellata is considered one of the most tolerant taxa in coralligenous assemblages of both sediment and nutrient enrichment (Balata et al. 2005, 2007, Piazzi et al. 2011). However, in contrast to Balata et al. (2011), we observed a high coverage of the prostrate ochrophyte Zanardinia typus on the inshore outcrops.

Differences between outcrops of clusters 2 and 4 could be related to water quality. Indeed, a low concentration of 

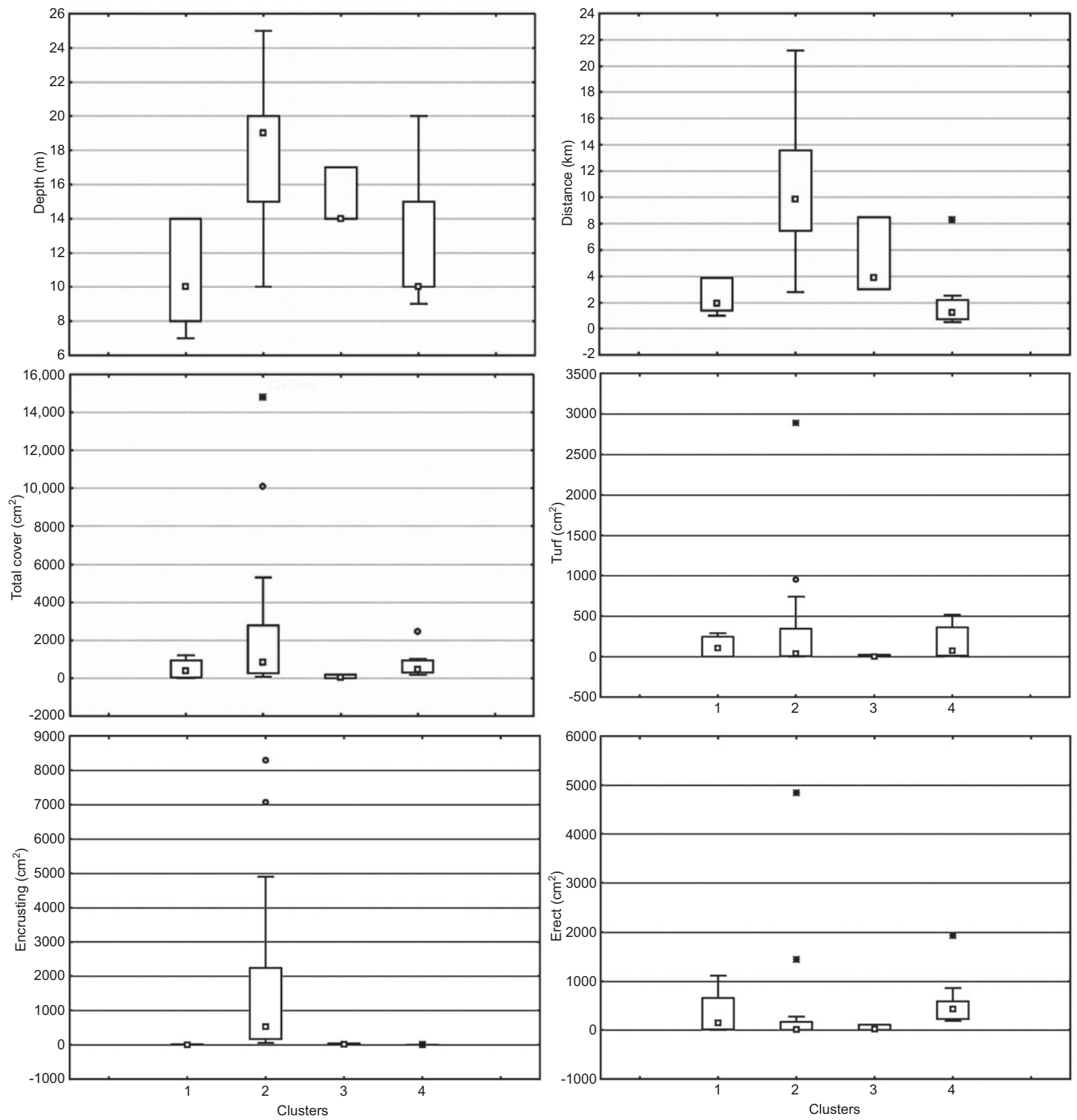

Figure 4 Box-and-whisker plots of depth, distance from coast, total cover, covers of turf and encrusting and erect algae for the four clusters identified in self-organizing map (SOM) analysis. Boxes include the median, the inter-quartile range with the 25th and 75th percentiles; the upper and lower whiskers mark the maximum and minimum values, hollow dots the outliers and asterisks the extreme values.

inorganic nutrients and chlorophyll $a$ distinguish offshore stations of cluster 2 from the others (Bernardi-Aubry et al. 2006, ARPAV 2008, Solidoro et al. 2009). Cluster 2, which includes deep and offshore rocky outcrops situated eastward of the Venice lagoon up to the Gulf of Trieste, was characterized by a high mean number of species (29.5) total coverage (26.3\%) and Rhodophyta coverage (20.8\%). Moreover, these rocky outcrops were characterized by taxa that are also common on typical Mediterranean coralligenous assemblages, such as Peyssonnelia rosamarina, P. harveyana, P. polymorpha, P. squamaria, Lithophyllum pustulatum, L. incrustans, L. racemus, Lithothamnion philippii, L. minervae, Mesophyllum macroblastum, M. alternans and Neogoniolithon mamillosum. Cluster 4 grouped the shallow inshore rocky outcrops that were almost all located between the sea inlets of Malamocco and Chioggia; they were characterized by a medium-high number of taxa and a low total coverage and included 
species that are commonly found on both coastal natural and artificial hard substrata (Curiel et al. 1999, Falace 2000, Falace et al. 2010c). Cluster 1 included rocky outcrops situated between the sea inlets of Lido and Malamocco at intermediate depths and distances from the coast. These outcrops had reduced mean numbers of taxa and coverage and a prevalence of Cryptonemia lomation, Rhodophyllis divaricata, Rhodymenia ardissonei and Lithophyllum pustulatum. Finally, the three rocky outcrops that define cluster 3 bore assemblages and characteristics that were intermediate between those found in cluster 2 and clusters 1 and 4 . The reduced total algal coverage, the shallow depth and the habitat preferences of algal species characterizing the assemblages included in clusters 1, 3 and 4 suggest a great influence of coastal-related pressures. Indeed, all of them are situated off the Venice lagoon, where erosion dominates over deposition processes, and there is a tendency for sediment loss (Bianchi et al. 2004, Defendi et al. 2010) through the inlets (Gačić et al. 2004). Sediment transport reaches $385 \times 10^{3} \mathrm{t}$ year ${ }^{-1}$ through the Lido inlet, $48 \times 10^{3} \mathrm{t}_{\text {year }}{ }^{-1}$ through the Malamocco inlet and $140 \times 10^{3} \mathrm{t}_{\text {year }}{ }^{-1}$ through the Chioggia inlet (Defendi et al. 2010). Limited transparency of water and high loads of total suspended matter in the sea inlets have also been reported (Bianchi et al. 2004), which most probably limit the development of sensitive algal taxa and, in particular, the growth of the erect algae in areas close to the inlets. A similar effect can be hypothesized for the site PRIM situated off Grado Lagoon in an area affected not only by the outflow from the lagoon, but also by the plume of the Isonzo river flowing along the northwestern coast of the Gulf of Trieste (Solidoro et al. 2007a). The mathematical models of water fluxes of the Venice lagoon (D'Alpaos and Martini 2005) stress that the long dams favor the transport of dissolved and particulate matter to the sea at several $\mathrm{km}$ distance, with a consequent fall out over the outcrops located at reduced or intermediate distances from the coast. Furthermore, these rocky outcrops also receive many visits from recreational fishermen and shellfish collectors, which indicates that they are often physically disturbed. The area south of the Lido inlet is also characterized by high salinity and lower nutrient concentrations and chlorophyll (Solidoro et al. 2007b), thus showing oligotrophic characteristics.

Rocky outcrops situated off the Lido inlet are very diverse, indicating that it is an area of great environmental complexity and/or strong gradients. Indeed, there is a change in algal assemblages from cluster 4 to 1,3 and 2 going offshore (Figure 4). The complexity is most probably due to the high hydrodynamism of this area, with Venice lagoon waters mixing with currents flowing along the coast from northeast to southwest, bringing nutrientenriched waters from the estuaries of several rivers (Piave, Livenza, Sile). The Lido inlet also concentrates the highest vessel traffic, thus possible effects of physical disturbance and species translocation on hulls or in ballast waters on structure and composition of macroalgal communities on rocky outcrops cannot be disregarded.

Little information is available in the literature on the effects of nutrient enrichment on coralligenous assemblages (Piazzi et al. 2011), and, in the northern Adriatic, the response of algal subtidal communities to nutrients should be the subject of further in-depth investigations.

Among the rocky outcrops, BARD and SPI deserve closer inspection because they were characterized by the highest number of taxa (61-97) and total coverage $(100 \%-148 \%)$. Encrusting algal coverage $(71 \%-83 \%$ coverage) was also high and was represented by some of the main coralligenous builders, such as such as Mesophyllum alternans, Neogoniolithon mamillosum and Lithophyllum stictaeforme (Falace et al. 2011, Gordini et al. 2012). On these two outcrops, we also found Lithothamnion philippii, L. minervae and Lithophyllum pustulatum, which significantly contribute to the bioconstruction process in these and other biogenic reefs of the northern Adriatic (Falace et al. 2010a, 2011, 2012, Gordini et al. 2012). Moreover, Mesophyllum macroblastum, which is characteristic of the Mediterranean coralligenous flora, was identified for the first time in the Adriatic on the SPI outcrop (Kaleb et al. 2011). Some erect algae, such as Arthrocladia villosa, Cryptonemia lomation, Dictyota dichotoma v. dichotoma, Halymenia elongata, $H$. floresii, Nithophyllum punctatum, Rhodymenia ardissonei, Scinaia complanata and Taonia atomaria, were also abundant. The surrounding sediments comprised sandy to muddy bottoms with maërlforming free-living coralline algae, such as Lithothamnion corallioides, Phymatolithon calcareum, Lithothamnion minervae and Lithophyllum racemus (Falace et al. 2010a, Gordini et al. 2012). These two outcrops have recently been designated as Sites of Community Interest (SCI) for the Friuli Venezia Giulia, together with some outcrops in the area of Chioggia in Veneto, because of their high biodiversity and ecological interest (Falace et al. 2009).

Northern Adriatic rocky outcrops show striking differences from typical Mediterranean coralligenous assemblages. Articulated coralline algae are not present in northern Adriatic rocky outcrops, but the most outstanding absence is that of the green erect alga Halimeda tuna (J. Ellis et Solander) J.V. Lamouroux, one of the most significant species in Mediterranean coralligenous assemblages (Ballesteros 1991, 2006). Moreover, Flabellia petiolata was found only in four samples, with a very low coverage 
$(<1 \%)$. Flabellia petiolata and $H$. tuna have been reported as species sensitive to sediment and nutrient enrichments (Balata et al. 2005, 2011), and there has been an upward migration of these two species from the lower sublittoral zone to the eulittoral zone in relation to increasing turbidity in the Gulf of Trieste (Falace 2000, Falace et al. 2010c).

None of the endangered species reported by Ballesteros (2006) were observed in our samples. In contrast, up to seven alien species (Antithamnion hubbsii, Desmarestia viridis, Heterosiphonia japonica, Neosiphonia harveyi, Polysiphonia morrowii, Polysiphonia stricta, Solieria filiformis) (Zenetos et al. 2010) were identified in our samples.

In summary, this contribution is the first extensive review on macroalgal assemblages on rocky outcrops in the northern Adriatic Sea. Although this whole area is subject to strong environmental (river mouths, sedimentation, exchanges with coastal lagoons) and anthropogenic pressures (overfishing, coastal eutrophication, maritime tourism and commercial traffic), these submerged rocky habitats have a high macroalgal species diversity, similar to that already observed for the macrozoobenthic assemblages. The results obtained in this study may be used as a baseline for the macroalgal assemblages of the rocky outcrops from the northern Adriatic Sea within the context of the future enforcement by the EU maritime policy of the Marine Strategy Framework Directive, which is aimed at the promotion of the sustainable use of the seas and the conservation of marine ecosystems.

Acknowledgments: Authors would like to thank Dr. Gianpiero Cossarini for his help in the interpretation of the hydrodynamical and biogeochemical interactions between the Venice lagoon and the Adriatic Sea.

Received May 30, 2012; accepted August 7, 2012; online first September 5, 2012

\section{Appendix}

\section{Appendix I Floristic list}

\section{Rhodophyta}

Acrochaetiaceae

Acrochaetium microscopicum (Nägeli ex Kützing) Nägeli

Acrosorium ciliolatum (Harvey) Kylin

Aglaothamnion sp.

Aglaothamnion tenuissimum (Bonnemaison)

Feldmann-Mazoyer

Aglaothamnion tripinnatum (C. Agardh)

Feldmann-Mazoyer

Anotrichium furcellatum (J. Agardh) Baldock

Antithamnion cruciatum (C. Agardh) Nägeli

Antithamnion hubbsii E.Y. Dawson

Antithamnion tenuissimum (Hauck) Schiffner

Apoglossum ruscifolium (Turner) J. Agardh

Asparagopsis armata Harvey [Falkenbergia rufolanosa

(Harvey) F. Schmitz]

Bangia fuscopurpurea (Dillwyn) Lyngbye

Botryocladia boergesenii Feldmann

Botryocladia botryoides (Wulfen) Feldmann

Botryocladia chiajeana (Meneghini) Kylin

Botryocladia microphysa (Hauck) Kylin

Callithamnion corymbosum (Smith) Lyngbye

Calosiphonia dalmatica (Kützing) Bornet et Flahault

Caulacanthus ustulatus (Mertens ex Turner) Kützing

Centroceras clavulatum (C. Agardh) Montagne

Ceramium ciliatum (J. Ellis) Ducluzeau
Ceramium cimbricum H.E. Petersen

Ceramium codii (H. Richards) Feldmann-Mazoyer

Ceramium comptum Børgesen

Ceramium diaphanum (Lightfoof) Roth

Ceramium siliquosum (Kützing) Maggs et Hommersand

Ceramium virgatum Roth

Champia parvula (C. Agardh) Harvey

Chondracanthus acicularis (Roth) Fredericq

Chondria capillaris (Hudson) M.J. Wynne

Chondria dasyphylla (Woodward) C. Agardh

Compsothamnion thuyoides (Smith) Nägeli

Crouania attenuata (C. Agardh) J. Agardh

Cryptonemia lomation (Bertoloni) J. Agardh

Dasya baillouviana (S.G. Gmelin) Montagne

Dasya corymbifera J. Agardh

Dasya hutchinsiae Harvey

Dudresnaya verticillata (Withering) Le Jolis

Erythrocladia irregularis Rosenvinge

Erythrotrichia carnea (Dillwyn) J. Agardh

Eupogodon planus (C. Agardh) Kützing

Gastroclonium reflexum (Chauvin) Kützing

Gastroclonium clavatum (Roth) Ardissone

Gelidiella nigrescens (Feldmann) Feldmann et Hamel

Gelidium pusillum (Stackhouse) Le Jolis

Gracilaria bursa-pastoris (S.G. Gmelin) P.C. Silva

Gracilariopsis longissima (S.G. Gmelin) Steentoft et al.

Griffithsia schousboei Montagne

Gulsonia nodulosa (Ercegovic) Feldmann et G. Feldmann 
Halymenia elongata C. Agardh

Halymenia floresii (Clemente) C. Agardh

Halymenia floresii v. ulvoidea Codomier

Herposiphonia secunda (C. Agardh) Ambronn

Heterosiphonia japonica Yendo

Hydrolithon boreale (Foslie) Y.M. Chamberlain

Hydrolithon farinosum (J.V. Lam.) D. Penrose et

Y.M. Chamberlain

Hypnea musciformis (Wulfen) J.V. Lamouroux

Hypoglossum hypoglossoides (Stackhouse) Collins et Hervey Kallymenia sp.

Laurencia obtusa (Hudson) J.V. Lamouroux

Lithophyllum corallinae (P.L. Crouan et H.M. Crouan)

Heydrich

Lithophyllum cystoseirae (Hauck) Heydrich

Lithophyllum incrustans Philippi

Lithophyllum pustulatum (J.V. Lamoroux) Foslie

Lithophyllum racemus (Lamarck) Foslie

Lithophyllum stictaeforme (J.E. Areschoug) Hauck

Lithothamnion corallioides (P.L. Crouan et H.M. Crouan)

P.L. Crouan et H.M. Crouan

Lithothamnion minervae Basso

Lithothamnion philippii Foslie

Lithothamnion sonderi Hauck

Lomentaria chylocladiella Funk

Lomentaria clavellosa (Turner) Gaillon

Lomentaria verticillata Funk

Melobesia membranacea (Esper) J.V. Lamouroux

Meredithia microphylla (J. Agardh) J. Agardh

Mesophyllum alternans (Foslie) Cabioch et Mendoza

Mesophyllum macroblastum (Foslie) Adey

Monosporus pedicellatus (Smith) Solier

Myriogramme minuta Kylin

Neogoniolithon brassica-florida (Harvey) Setchell et

L.R. Mason

Neogoniolithon mamillosum (Hauck) Setchell et L.R. Mason

Neosiphonia harveyi (J.W. Bailey) M.S. Kim, H.G. Choi,

Guiry et G.W. Sanders

Nitophyllum punctatum (Stackhouse) Greville

Palisada perforata (Bory de Saint-Vincent) K.W. Nam

Parviphycus tenuissimus B. Santelices

Peyssonnelia dubyi P. et H. Crouan

Peyssonnelia harveyana P. et H. Crouan ex J. Agardh

Peyssonnelia polymorpha (Zanardini) F. Schmitz

Peyssonnelia rosa-marina Boudouresque et Denizot

Peyssonnelia rubra (Greville) J. Agardh

Peyssonnelia squamaria (S.G. Gmelin) Decaisne

Phyllophora sicula (Kützing) Guiry et L.M. Irvine

Phymatolithon calcareum (Pallas) W.H. Adey et

D.L. McKibbin

Phymatolithon lenormandii (J.E. Areschoug) W.H. Adey
Pleonosporium borreri (Smith) Nägeli

Plocamium cartilagineum (Linnaeus) P.S. Dixon

Pneophyllum confervicola (Kützing) Y.M. Chamberlain

Pneophyllum fragile Kützing

Polysiphonia denudata (Dillwyn) Greville ex Harvey

Polysiphonia elongata (Hudson) Sprengel

Polysiphonia furcellata (C. Agardh) Harvey

Polysiphonia morrowii Harvey

Polysiphonia sanguinea (C. Agardh) Zanardini

Polysiphonia scopulorum Harvey

Polysiphonia stricta (Dillwyn) Greville

Predaea ollivieri Feldmann

Pterosiphonia pennata (C. Agardh) Sauvageau

Pterothamnion crispum (Ducluzeau) Nägeli

Pterothamnion plumula (J. Ellis) Nägeli

Ptilothamnion pluma (Dillwyn) Thuret

Radicilingua reptans (Kylin) Papenfuss

Radicilingua thysanorhizans (Holmes) Papenfuss

Rhodophyllis divaricata (Stackhouse) Papenfuss

Rhodymenia ardissonei (Kuntze) Feldmann

Rhodymenia pseudopalmata (J.V. Lamouroux) P.C. Silva

Scinaia complanata (F.S. Collins) A.D. Cotton

Seirospora interrupta (Smith) F. Schmitz

Solieria filiformis (Kützing) P.W. Gabrielson

Spermothamnion repens (Dillwyn) Rosenvinge

Spermothamnion strictum (C. Agardh) Ardissone

Sphondylothamnion multifidum (Hudson) Nägeli

Spyridia filamentosa (Wulfen) Harvey

Stylonema alsidii (Zanardini) K.M. Drew

Ochrophyta (Phaeophyceae)

Arthrocladia villosa (Hudson) Duby

Cladosiphon zosterae (J. Agardh) Kylin

Cutleria chilosa (Falkenberg) P.C.Silva

Cutleria multifida (Turner) Greville [Aglaozonia parvula

(Greville) Zanardini]

Cystoseira sp.

Desmarestia viridis (O.F. Müller) J.V. Lamouroux

Dictyopteris polypodioides (A.P. De Candolle) J.V. Lamouroux

Dictyota dichotoma (Hudson) J.V. Lamouroux v. dichotoma

Dictyota dichotoma (Hudson) J.V. Lamouroux v. intricata

(C. Agardh) Greville

Dictyota linearis (C. Agardh) Greville

Dictyota spiralis Montagne

Ectocarpus siliculosus (Dillwyn) Lyngbye v. siliculosus

Halopteris filicina (Grateloup) Kützing

Hincksia ovata (Kjellman) P.C. Silva

Hincksia sandriana (Zanardini) P.C. Silva

Myriactula stellulata (Harvey) Levring

Myrionema orbiculare J. Agardh

Nereia filiformis (J. Agardh) Zanardini 
Spermatochnus paradoxus (Roth) Kützing

Sphacelaria cirrosa (Roth) C. Agardh

Sphacelaria plumula Zanardini

Sporochnus pedunculatus (Hudson) C. Agardh

Stilophora tenella (Esper) P.C. Silva

Taonia atomaria (Woodward) J. Agardh

Zanardinia typus (Nardo) P. C. Silva

\section{Chlorophyta}

Acrochaete viridis (Reinke) R. Nielsen

Acrochaete flustrae (Reinke) O’Kelly

Bryopsis hypnoides J.V. Lamouroux

Bryopsis plumosa (Hudson) C. Agardh

Chaetomorpha ligustica (Kützing) Kützing

Chaetomorpha linum (O.F. Müller) Kützing

Cladophora coelothrix Kützing

Cladophora dalmatica Kützing
Cladophora hutchinsiae (Dillwyn) Kützing

Cladophora laetevirens (Dillwyn) Kützing

Cladophora pellucida (Hudson) Kützing

Cladophora sericea (Hudson) Kützing

Cladophora vagabunda (Linnaeus) C. Hoeck

Derbesia tenuissima (Moris et De Notaris) P. et H. Crouan

Flabellia petiolata (Turra) Nizamuddin

Gayralia oxysperma (Kützing) K.L. Vinogradova ex Scagel et al.

Pseudochlorodesmis furcellata (Zanardini) Børgesen

Tellamia contorta Batters

Ulva flexuosa Wulfen

Ulva intestinalis Linnaeus

Ulva laetevirens Areschoug

Ulvella lens $\mathrm{P}$. et $\mathrm{H}$. Crouan

Ulvella setchellii P.J.L. Dangeard

Valonia utricularis (Roth) C. Agardh

\section{References}

AA.VV. 2010. Le tegnùe dell'Alto Adriatico: valorizzazione della risorsa marina attraverso lo studio di aree di pregio ambientale. Agenzia Regionale per la Prevenzione e protezione Ambientale del Veneto ARPAV (eds.), Venezia. pp. 203. Available at: http://www.arpa.veneto.it/arpavinforma/pubblicazioni.

Agenzia Regionale per la Prevenzione e protezione Ambientale del Veneto (ARPAV). 2008. Monitoraggio integrato dell'ambiente marino-costiero nella Regione Veneto. Gennaio - Dicembre 2008. Analisi dei dati osservati nell'anno 2008. Inedit. ARPAV, Venezia. pp. 87. Available at: http://www.arpa.veneto. it/acqua/docs/mc/rapporti_tecnici/Rapporto_Acque_ Marino\%20Costiere_2008.pdf

Artegiani, A., D. Bregant, E. Paschini, N. Pinardi, F. Raicich and A. Russo. 1997a. The Adriatic Sea general circulation. Part 1: air-sea interactions and water mass structure. J. Phys. Oceanogr. 27: 1492-1514.

Artegiani, A., D. Bregant, E. Paschini, N. Pinardi, F. Raicich and A. Russo. 1997b. The Adriatic Sea general circulation. Part 2: baroclinic circulation structure. J. Phys. Oceanogr. 27: 515-532.

Balata, D., L. Piazzi, D. Pica and F. Cinelli. 2004. Influenza della sedimentazione su un popolamento coralligeno Mediterraneo. Proceedings 14th Meeting of the Italian Society of Ecology (4-6 Ottobre), Siena, Italy. pp. 1-3.

Balata, D., L. Piazzi, E. Cecchi and F. Cinelli. 2005. Variability of Mediterranean coralligenous assemblages subject to local variation in sediment deposition. Mar. Environ. Res. 60: 403-421.

Balata, D., L. Piazzi and L. Benedetti-Cecchi. 2007. Sediment disturbance and loss of beta diversity on subtidal rocky reefs. Ecology 88: 2455-2461.

Balata, D., L. Piazzi and F. Rindi. 2011. Testing a new classification of morphological functional groups of marine macroalgae for the detection of responses to stress. Mar. Biol. 158: 2459-2469.

Ballesteros, E. 1991. Seasonality of growth and production of a deep-water population of Halimeda tuna (Chlorophyceae, Caulerpales) in the north-western Mediterranean. Bot. Mar. 34: 291-301.

Ballesteros, E. 2006. Mediterranean coralligenous assemblages: a synthesis of present knowledge. Oceanogr. Mar. Biol. Annu. Rev. 44: 23-195.

Bandelj, V., G. Socal, Y.S. Park Lek, J. Coppola, E. Camatti, E. Capuzzo, L. Milani and C. Solidoro. 2008. Analysis of multitrophic plankton assemblages in the Lagoon of Venice. Mar. Ecol. Prog. Ser. 368: 23-40.

Bernardi-Aubry, F., A. Berton, M. Bastianini, G. Socal and F. Acri. 2004. Phytoplankton succession in a coastal area of the NW Adriatic over 10 years of samplings (1990-1999). Cont. Shelf Res. 24: 97-115.

Bernardi-Aubry, F., F. Acri, M. Bastianini, F. Bianchi, D. Cassin, A. Pugnetti and G. Socal. 2006. Seasonal and interannual variations of phytoplankton in the Gulf of Venice (NAS). Chem. Ecol. 22: 71-91.

Bianchi, F., E. Ravagnan, F. Acri, F. Bernardi-Aubry, A. Boldrin, E. Camatti, D. Cassin and M. Turchetto. 2004. Variability and fluxes of hydrology, nutrients and particulate matter between the Venice Lagoon and the Adriatic Sea. Preliminary results (years 2001-2002). J. Mar. Syst. 51: 49-64.

Boudouresque, C.F. 1971. Méthodes d'étude qualitative et quantitative du benthos (en particulier du Phytobenthos). Téthys 3: 79-104.

Boudouresque, C.F. 1973. Recherches de bionomie analytique, structurale et expérimentale sur les peuplements benthiques sciaphiles de Méditerranée Occidentale (fraction algale). Les peuplements sciaphiles de mode relativement calme sur substrats durs. Bull. Mus. Hist. Nat. Marseille 33: 147-225. 
Braga, G. and A. Stefanon. 1969. Beachrock e Alto Adriatico: aspetti paleogeografici, climatici, morfologici ed ecologici del problema. Atti Ist. Veneto Sci., Lett. Arti, Classe di Sci. Mat. Nat. 77: 351-361.

Casellato, S. and S. Stefanon. 2008. Coralligenous habitat in the northern Adriatic Sea: an overview. Mar. Ecol. 29: 321-341.

Casellato, S., E. Sichirollo, A. Cristofoli, L. Masiero and S. Soresi. 2005. Biodiversità delle "tegnùe" di Chioggia, zona di tutela biologica del Nord Adriatico. Biol. Mar. Medit. 12: 69-77.

Casellato, S., L. Masiero, E. Sichirollo and S. Soresi. 2007. Hidden secrets of the Northern Adriatic: "Tegnùe", peculiar reefs. Cent. Eur. J. Biol. 2: 122-136.

Clarke, K.R. 1993. Non-parametric multivariate analyses of changes in community structure. Aust. J. Ecol. 18: 117-143.

Colantoni, P., G. Gabbianelli, L. Ceffa and C. Ceccolini.1998. Bottom features and gas seepages in the Adriatic Sea. In: Proceedings Vth International Conference on Gas in Marine Sediments, Bologna, Italy. pp. 28-31.

Conti, A., A. Stefanon and G.M. Zuppi. 2002. Gas seeps and rock formation in the northern Adriatic Sea. Cont. Shelf Res. 22: 2333-2344.

Curiel, D. and E. Molin. 2010. Comunità fitobentoniche di substrato solido. In: Agenzia Regionale per la Prevenzione e protezione Ambientale del Veneto ARPAV (eds.) Le tegnùe dell'Alto Adriatico: valorizzazione della risors a marina attraverso lo studio di aree di pregio ambientale. ARPAV, Venezia. pp. 62-79.

Curiel, D., G. Bellemo, M. Marzocchi, M. Iuri and M. Scattolin. 1999. Benthic marine algae of the inlets of the lagoon of Venice (Northern Adriatic Sea - Italy) concerning environmental conditions. Acta Adriatica 40: 111-121.

Curiel, D., G. Orel and M. Marzocchi. 2001. Prime indagini sui popolamenti algali degli affioramenti rocciosi del Nord Adriatico. Boll. Soc. Adriat. Sci. 80: 3-16.

Curiel, D., A. Rismondo, C. Miotti, E. Checchin, C. Dri, G. Cecconi, C. Cerasuolo and M. Marzocchi. 2010a. Le macroalghe degli affioramenti rocciosi (tegnùe) del litorale veneto. Lavori Soc. Ven. Sc. Nat. 35: 39-55.

Curiel, D., E. Checchin, C. Dri, C. Miotti, A. Rismondo, L. Mizzan and M. Marzocchi. 2010b. Le macroalghe degli affioramenti rocciosi (tegnùe) antistanti le bocche di porto della Laguna di Venezia. Boll. Mus. civ. St. Nat. Venezia 61: 5-20.

D'Alpaos, L. and P. Martini. 2005. The influence of the inlet configuration on sediment loss in the Venice Lagoon. In: (C.A. Fletcher and T. Spencer, eds.) Flooding and environmental challenges for Venice and its lagoon. State of Knowledge. University of Cambridge, Cambridge. pp. 419-430.

Defendi, V., V. Kovacevic, F. Arena and L. Zaggia. 2010. Estimating sediment transport from acoustic measurements in the Venice Lagoon inlets. Cont. Shelf Res. 30: 883-893.

Falace, A. 2000. Variazioni fisionomiche spazio-temporali della vegetazione sommersa del Golfo di Trieste: Analisi delle principali influenze ambientali. Ph.D. Dissertation, University of Trieste. Italy. pp. 202.

Falace, A., S. Kaleb and D. Curiel. 2009. Implementazione dei S.I.C. marini italiani. Biol. Mar. Medit. 16: 82-83.

Falace, A., S. Kaleb and D. Poloniato. 2010a. Macrofitobenthos. In: (E. Gordini and S. Ciriaco, eds.) Trezze o "Grebeni": Biotopi e geotopi dell'Alto Adriatico. ArtGroup, Trieste. pp. 55-60.
Falace, A., S. Kaleb, D. Poloniato and A. Malusà. 2010b. Alghe. In: (E. Gordini and S. Ciriaco, eds.) Trezze o "Grebeni": Biotopi e geotopi dell'Alto Adriatico. ArtGroup, Trieste. pp. 107-119.

Falace, A., G. Alongi, M. Cormaci, G. Furnari, D. Curiel, E. Cecere and A. Petrocelli. 2010c. Changes in the benthic algae along the Adriatic Sea in the last three decades. Chem. Ecol. 26: 77-90.

Falace, A., S. Kaleb, M. Orlando-Bonaca, B. Mavric and L. Lipej. 2011. First contribution to the knowledge of coralline algae distribution in the Slovenian circalittoral zone (Northern Adriatic). Annales Ser. Hist. Nat. 21: 27-40.

Falace, A., G. Alongi, S. Kaleb and M. Cormaci. 2012. Guida alle alghe del Golfo di Trieste. Ed. Goliardiche, Trieste. pp. 168.

Franco, P. 1984. Fattori influenti sulla produttività primaria dell'Adriatico Settentrionale. Boll. Oceanol. Teor. Applic. 11: 125-140.

Gabriele, M., A. Bellot, D. Gallotti and R. Brunetti. 1999. Sublittoral hard substrate communities of the northern Adriatic Sea. Cah. Biol. Mar. 40: 65-76.

Gačić, M., I. Mancero Mosquera, V. Kovacevic, A. Mazzoldi, V. Cardin, F. Arena and G. Gelsi. 2004. Temporal variations of water flow between the Venetian lagoon and the open sea. J. Mar. Syst. 51: 33-48.

Giraudel, J.L. and S. Lek. 2001. A comparison of self-organizing map algorithm and some conventional statistical methods for ecological community ordination. Ecol. Modell. 146: 29-339.

Gordini, E., R. Marocco, G. Tunis and R. Ramella. 2004. The cemented deposits of the Trieste Gulf (Northern Adriatic Sea): areal distribution, geomorphologic characteristics and high resolution seismic survey. J. Quaternary Sci. 17: 555-563.

Gordini, E., A. Falace, S. Kaleb, F. Donda, R. Marocco and G. Tunis. 2012. Methane-related carbonate cementation of marine sediments and related macroalgal coralligenous assemblages in the Northern Adriatic Sea. In: (P.T. Harris and E.K. Baker, eds.) Seafloor geomorphology as benthic habitat: GeoHab atlas of seafloor geomorphic features and benthic habitats. Elsevier, Amsterdam. pp. 185-200.

Hong, J.S. 1980. Étude faunistique d'un fond de concrétionnement de type coralligène soumis à un gradient de pollution en Méditerranée nord-occidentale (Golfe de Fos). Thèse de Doctorat. Université d’Aix -Marseille II. pp. 134.

Kaleb, S., A. Falace, G. Sartoni and W. Woelkerling. 2011. Morphology-anatomy of Mesophyllum macroblastum (Hapalidiaceae, Corallinales, Rhodophyta) in the Northern Adriatic Sea and a key to Mediterranean species of the genus. Cryptogamie: Algol. 32: 223-242.

Kohonen, T. 2001. Self-organizing maps. 3rd ed. Springer-Verlag, Heidelberg. pp. 501.

Laborel, J. 1987. Marine biogenic constructions in the Mediterranean. Rep. Sci. Par natl. Port-Cros 13: 97-126.

Legendre, P. and E.D. Gallagher. 2001. Ecologically meaningful transformations for ordination of species data. Oecologia 129: 271-280.

Legendre, P. and L. Legendre. 1998. Numerical ecology. 2nd ed. Elsevier Science B.V., Amsterdam. pp. 853.

Lek, S. and J.F. Guégan. 1999. Artificial neural networks as a tool in ecological modelling, an introduction. Ecol. Modell. 120: 65-73.

Mizzan, L. 1992. Malacocenosi e faune associate in due stazioni alto adriatiche a substrati solidi. Boll. Mus. civ. St. Nat. Venezia 41: 7-54. 
Molin, E., G. Pessa and A. Rismondo. 2010. Comunità macrozoobentonica di substrato solido. In: Agenzia Regionale per la Prevenzione e protezione Ambientale del Veneto ARPAV (eds.) Le tegnùe dell'Alto Adriatico: valorizzazione della risorsa marina attraverso lo studio di aree di pregio ambientale. ARPAV, Venezia. pp. 52-61.

Morganti, C., S. Cocito and S. Sgorbini. 2001. Contribution of biocostructor to coralligenous assemblages exposed to sediment deposition. Biol. Mar. Medit. 8: 283-286.

Newton, R. and A. Stefanon. 1975. The 'Tegnue de Ciosa' area: patch reefs in the Northern Adriatic Sea. Mar. Geol. 8: 27-33.

Park, Y.S., T.S. Chon, I.S. Kwak and S. Lek. 2004. Hierarchical community classification and assessment of aquatic ecosystems using artificial neural networks. Sci. Total Environ. 327: 105-122.

Pérès, J.M. and J. Picard. 1964. Nouveau manuel de bionomie benthique de la mer Méditerranée. Rec. Trav. Stat. Mar. Endoume 31: 1-131.

Piazzi, L., D. Balata, M. Pertusati and F. Cinelli. 2004. Spatial and temporal variability of Mediterranean macroalgal coralligenous assemblages in relation to habitat and substratum inclination. Bot. Mar. 47: 105-115.

Piazzi, L., P. Gennaro and D. Balata. 2011. Effects of nutrient enrichment on macroalgal coralligenous assemblages. Mar. Poll. Bull. 62: 1830-1835.

Ponti, M. and P. Mescalchin. 2008. Meraviglie sommerse delle "Tegnùe". Guida alla scoperta degli organismi marini. Associazione "Tegnùe di Chioggia"- onlus. Editrice La Mandragora, Imola. pp. 424.

Ponti, M., F. Fava and M. Abbiati. 2011. Spatio-temporal variability of epibenthic assemblages on subtidal biogenic reefs in the northern Adriatic Sea. Mar. Biol. 158: 1447-1459.

Sartoretto, S. 1996. Vitesse de croissance et bioérosion des concrétionnements "coralligènes" de Méditerranée nord-occidentale. Rapport avec les variations Holocènes du niveau marin. Thèse Doctorat d'Écologie, Université d'Aix -Marseille, II. pp. 194.

Solazzi, A. and C. Tolomio. 1981. Alghe bentoniche delle "tegnue de Ciosa”. Adriatico Nord-occidentale. Studi trentini Sci. Nat. 58: 463-470.

Solidoro, C., V. Bandelj, P. Barbieri, G. Cossarini and S. Fonda Umani. 2007a. Understanding dynamic of biogeochemical properties in the northern Adriatic Sea by using self-organizing maps and k-means clustering. J. Geophys. Res. 112: C07S90, DOI: $10.1029 / 2006 J C 003553$.

Solidoro, C., V. Bandelj, G. Cossarini, D. Melaku Canu, S. Trevisani and M. Bastianini. 2007b. Biogeochemical properties in the coastal area of the North-western Adriatic Sea. In: (P. Campostrini, ed.) Scientific research and safeguarding of Venice 2007. Corila Research Programme 2004-2006. Volume VI 2006 Results. CORILA, Venice, Italy. pp. 371-384.

Solidoro, C., M. Bastianini, V. Bandelj, R. Codermatz, G. Cossarini, D. Melaku Canu, E. Ravagnan, S. Salon and S. Trevisani. 2009. Current state, scales of variability, and trends of biogeochemical properties in the northern Adriatic Sea. J. Geophys. Res. 114: C07S91, DOI: 10.1029/2008JC004838.

Soresi, S., A. Cristofoli, M. Masiero and S. Casellato. 2004. Benthic communities of rocky outcrops in the Northern Adriatic Sea: a quantitative survey. Rapp. P-V, Comm. Int. Explor. Sci. Mer Mediterr. 37: 551-552.

Stefanon, A. 1970. The role of beachrock in the study of the evolution of the North Adriatic Sea. Mem. Biogeogr. Adriat. 8: 79-99.

Stefanon, A. and A. Boldrin. 1982. The oxygen crisis of the Northern Adriatic Sea waters in late fall 1977 and its effects on benthic communities. In: (J. Blanchard, J. Mair and I. Morrison, eds.). Proceedings 6th International Science Symposium World Underwater Federation (CMAS). National Environmental Research Council, Edinburgh. pp. 167-175.

Stefanon, A. and G.M. Zuppi. 2000. Recent carbonate rock formation in the Northern Adriatic Sea. Hydrogeologie 4: 3-10.

Trincardi, F., A. Correggiari and M. Roveri. 1994. Late quaternary transgressive erosion and deposition in a modern epicontinental shelf: the Adriatic semienclosed basin. Geo Mar. Lett. 14: 41-51.

Zenetos, A., S. Gofas, M. Verlaque, M. Çinar, E. García Raso, C.N. Bianchi, C. Morri, E. Azzurro, M. Bilecenoglu, C. Froglia, I. Siokou, D. Violanti, A. Sfriso, G. San Martín, A. Giangrande, T. Katagan, E. Ballesteros, A. Ramos Esplá, F. Mastrototaro, O. Ocaña, A. Zingone, M.C. Gambi and N. Streftaris. 2010. Alien species in the Mediterranean areas of the European Union's Marine Strategy Framework Directive (MSFD) by 2010. Part I. Spatial distribution. Medit. Mar. Sci. 11: 381-493. 